\title{
MEMBERDAYAKAN MASYARAKAT DESA MELALUI PEMBERIAN KETERAMPILAN DAN PENDAMPINGAN PERUBAHAN SIKAP
}

\author{
Basuki, Aida Vitria, dan Susiladewi \\ Fakultas Ekonomi, Universitas Islam Kalimantan \\ E-mail :msibasukidr@gmail.com
}

\begin{abstract}
ABSTRAK
Pemberdayaan masyarakat diartikan sebagai usaha-usaha sadar yang bersifat terencana, sistematik, dan berkesinambungan untuk membangun kemandirian sosial, ekonomi, dan politik masyarakat dengan mengelola potensi sumber daya yang mereka miliki untuk mencapai kesejahteraan sosial yang bersifat berkelanjutan. Salah satu bentuk pemberdayaan masyarakat adalah berupa memberikan kesadaran terhadap adanya peluang-peluang baru dalam meningkatkan kesejahteraan hidupnya, memberikan dorongan dan perubahan sikap serta bisa juga dengan memberikan pelatihan-pelatihan dan pendampingan dalam membuka usaha secara mandiri. Melalui kegiatan pemberdayaan masyarakat ini, usaha dapat dibuat untuk merubah sikap masyarakat terhadap pencapaian kesejahteraan yang lebih baik.
\end{abstract}

Kata Kunci : Pemberdayaan masyarakat, Peningkatan Kemampuan, perubahan sikap

\section{PENDAHULUAN}

Masyarakat pedesaan merupakan masyarakat yang hidup tenang dengan kelimpahan hasil pertanian. Namun sejalan dengan perkembangan wilayah dan perubahan pola hidup serta keadaan alam mengakibat kehidupan dipedesaan tergerus oleh masalah tersebut. Untuk itulah diperlukan suatu model pemberdayaan ekonomi petani tradisional daerah pertanian dalam upaya mempertahankan dan meningkatkan pendapatan mereka. Menurut Kusnadi (2009) pemberdayaan masyarakat diartikan sebagai usahausaha sadar yang bersifat terencana, sistematik, dan berkesinambungan untuk membangun kemandirian sosial, ekonomi, dan politik masyarakat dengan mengelola potensi sumber daya yang mereka miliki untuk mencapai kesejahteraan sosial yang bersifat berkelanjutan.

Salah satu bentuk pemberdayaan masyarakat adalah berupa memberikan kesadaran terhadap adanya peluangpeluang baru dalam meningkatkan kesejahteraan hidupnya dan bisa juga dengan memberikan pelatihan-pelatihan dalam membuka usaha secara mandiri.

Diperlukan prasyarat/kondisi dan proses yang sistemik didalam pemberdayaan ekonomi rakyat terutama yang ter-golong masyarakat miskin, 
seperti masyarakat petani tradisional di pedesaan. Prasyarat/kondisi yang dimaksudkan adalah: (1) adanya kondisi pemberdayaan; (2) memberikan kesempatan agar masya-rakat semakin berdaya; (3) perlindungan agar keberdayaan dapat berkembang; (4) meningkatkan kemampuan agar semakin berdaya, dan (5) fungsi pemerintah. Sedangkan proses pemberdayaan masyarakat miskin dapat dilakukan secara bertahap melalui tiga fase yaitu: (1) fase inisial, dimana pemerintah yang paling dominan dan rakyat bersifat pasif; (2) fase partisipatoris; dimana proses pemberdayaan berasal dari pemerintah bersama masyarakat, dan (3) fase emansipatoris, masyarakat sudah dapat menemukan kekuatan dirinya sehingga dapat melakukan pembaharuanpembaharuan dalam mengaktualisasikan dirinya (Pranaka \& Prijono, 2016), dengan bermuara pada tiga sasaran pokok yaitu: (1) meningkatnya pendapatan masyarakat di tingkat bawah dan menurunnya jumlah penduduk yang terdapat di bawah garis kemiskinan; (2) berkembangnya kapasitas masyarakat untuk meningkatkan kegiatan sosial ekonomi produktif masyarakat di daerah pedesaan; dan (3) berkembangnya kemampuan masyarakat dan meningkatnya kapasitas kelembagaan masyarakat, baik aparat maupun warga (Sumodiningrat 2009 dalam Juliantara, 2009), dan dilakukan melalui tiga arah yaitu: (1) penciptaan suasana dan iklim yang memungkinkan potensi masyarakat berkembang (enabling); (2) penguatan potensi atau daya yang dimiliki oleh masyarakat (empowering); dan (3) perlindungan (protecting) terhadap pihak yang lemah agar jangan bertambah lemah serta mencegah terjadi persaingan yang tidak seimbang dan eksploitasi yang kuat atas yang lemah (Kartasasmita, 2016), serta menggunakan tiga pendekatan, yaitu: pertama, pendekatan yang terarah, artinya pemberdayaan masyarakat harus terarah yakni berpihak kepada orang miskin, kedua, pendekatan kelompok, artinya secara bersama-sama untuk memudahkan pemecahan masalah yang dihadapi.

Ketiga, pendekatan pendampingan, artinya selama proses pembentukan dan penyelenggaraan kelompok masyarakat miskin perlu didampingi oleh pendamping yang profesional sebagai fasilitator, komunikator, dan dinamisator terhadap 
kelompok untuk mempercepat tercapainya kemandirian (Kartasasmita, 2016 dalam Soegijoko, 2017).

Merumuskan

model

pemberdayaan ekonomi petani

tradisional harus memperhatikan karakteristik mereka (Frith 2007 dalam Mubyarto 2014), secara geografis mereka sebagai sebuah masyarakat yang memiliki kebudayaan tertentu yang menjadi pembeda dengan kelompok sosial lainnya (Kusnadi, 2009), dan mereka adalah pekerja keras, cerdik, dan ulet sehingga dapat bertahan hidup dan melepaskan diri dari belenggu rantai kemiskinan yaitu kemiskinan itu sendiri (Chambers,2013).

Pekerjaan sebagai petani oleh sebagian besar $(82 \%)$ petani tradisional adalah pekerjaan atau sumber matapencaharian utama, disamping melakukan pekerjaan sampingan seperti: bertani di lahan sendiri dengan luas kurang dari 1 ha (37\%), buruh bangunan (30\%), buruh tani (17\%), dan tidak ada pekerjaan samping sebanyak 16\%. Pekerjaan sampingan akan mereka lakukan pada saat menunggu masa panen (74\%), jika masih ada waktu sisa sesudah ke sawah (15\%), dan jika menurut pengalaman mereka bukan tanam/panen (11\%). Mereka (82\%) menyatakan bahwa petani nelayan tradisional (sesama mereka) masih kurang, dan mereka tidak merasakan bahwa rekan-rekannya sebagai saingan $(93 \%)$,

\section{KHALAYAK SASARAN}

Mitra sasaran dalam penyuluhan ini adalah ibu-ibu yang tergabung dalam kelompok PKK di Kelurahan Tatah Pamangkih Kabupaten Banjar.

\section{METODE}

Sosialisasi ini dilaksanakan sebagai bagian dari Pemberdayaan Pada Masyarakat dilakukan dengan memberikan ceramah dan dialog interaktif untuk mensosialisasikan pengetahuan serta pemberian keterampilan berupa pembuatan kuekue kering.

Metode yang digunakan dalam pengabdian ini melalui beberapa tahapan yaitu :

1. Tahap observasi kepada kelompok masyarakat yang akan dijadikan khalayak sasaran yaitu kelompok ibu-ibu petani.

2. Tahap pelaksanan kegiatan adalah melakukan kegiatan sosialisasi dengan mengikutsertakan partisipasi 
aktif peserta, pemberian keterampilan membuat kue-kue kering yang nanti di pasarkan ke toko terdekat.

3. Tahap evaluasi pelaksanaan yaitu dengan melakukan pengukuran tingkat keberhasilan dari kegiatan pemberdayaan kepada masyarakat dengan melihat jumlah respon dan tingkat keterampilan khalayak dalam membuat kue-kue kering.

\section{PEMBAHASAN}

Kegiatan pemberdayaan pada masyarakat ini diawali dengan melakukan observasi ke lapangan. Pada dasarnya masyarakat menginginkan suatu perbaikan pada kehidupan mereka, hanya asaja mereka tidak mengetahui apa yang harus dilakukan. Berdasarkan pengamatan pada awal pelaksanaan kegiatan pemberdayaan menunjukkan minat yang besar dari peserta yang terlihat dari antusiasme para peserta. Pertanyaan yang diajukan para peserta berkenaan dengan perubahan sikap sangat rinci, dari mempersiapkan perubahan sampai kepada apa yang harus dilakukan terhadap perubahan tersebut. Sebagian besar peserta (70 \%) memilih untuk merubah sikapnya untuk menerima halhal baru.

Perubahan sikap dimaknai sebagai penerimaan khalayak terhadap informasi terkait adanya metode-metode baru, pemikiran-pemikiran baru yang bertujuan untuk merubah cara pandang dalam mencapai kehidupan yang lebih baik.

Jadi dapat disimpulkan bahwa perubahan cara pandang terhadap sesuatu dapat merubah perilaku dalam menjalani kehidupan yang lebih baik. Pengetahuan tentang hal-hal baru sangat diperlukan agar dapat menentukan langkah-langkah yang diambil di masa yang akan datang. Hal ini memerlukan pendampingan secara terus menerus dalam upaya mengukur seberapa jauh telah terjadi perubahan sikap pada masyarakat.

Dalam materi sosialisasi sudah dijelaskan kepada peserta tentang perubahan yang sangat pesat, baik itu perubahan yang disebabkan oleh kecanggihan teknologi maupun perubahan karena keadaan alam dan kebijakan pemerintah. Bagi masyarakat pedesaan, sudah $60 \%$ memahami terhadap perubahan tersebut dan bersedia untuk secara perlahan merubah 
cara pandang dan perilaku kearah kehidupan yang lebih baik.

Evaluasi berikutnya dilaksanakan setelah kegiatan pemberian keterampilan kepada khalayak berupa pembuatan kue-kue kering sebagai salah satu upaya meningkatkan taraf hidup masyarakat sebagai tambahan penghasilan.

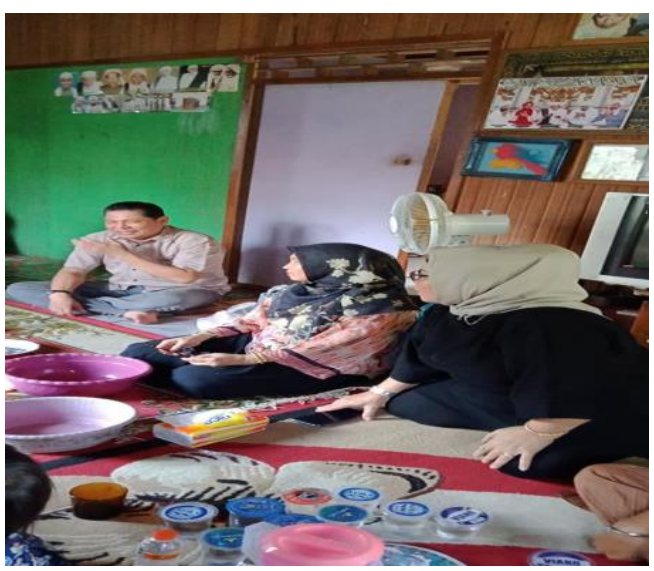

Gambar 1. Memberikan ceramah pengetahuan terhadap perubahan

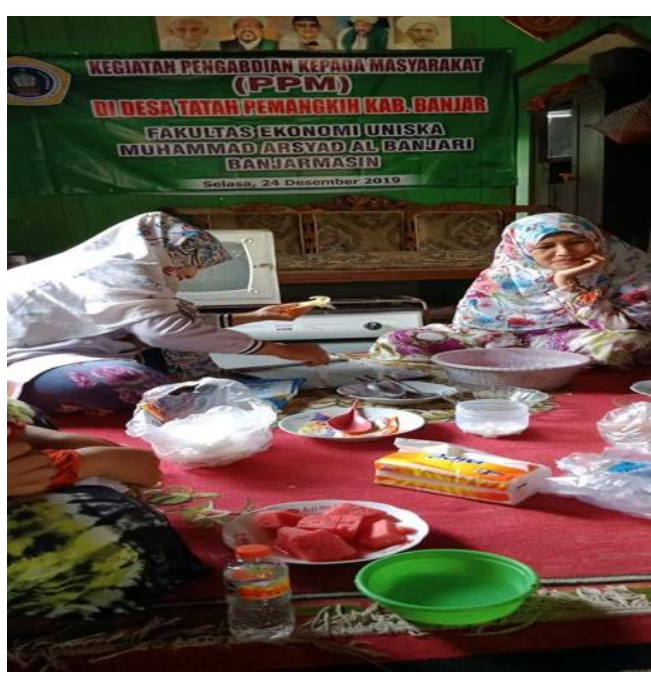

Gambar 2. Contoh pemberian keterampilan pembuatan kue-kue kering

\section{KESIMPULAN}

Pada era globalisasi terjadi perubahan besar dalam tata kehidupan masyarakat tidak terkecuali masyarakat di pedesaan. Perluasan dan pengembangan wilayah mengakibat terjadinya pengurangan lahan pertanian, dan adanya perubahan cuaca serta kebijakan-kebijakan pemerintah. Kegiatan pemberdayaan masyarakat merupakan salah satu solusi dalam memberikan pemdampingan kepada masyarakat agar memahami dan dapat mengantisipasi perubahan-perubahan yang sedang berlangsung tersebut.

\section{DAFTAR PUSTAKA}

Arif, Satria. (2003). Menuju Gerakan Kelautan. Jurnal Agrimedia.Volume 8 Nomor 2 April 2003

Basuki, Riyanto. (2006). Analisis Pengentasan Kemiskinan Masyarakat Pesisir Melalui Pengembangan Lembaga Keuangan Mikro: Studi Kasus di Pasuruan dan Tanggerang. Bogor. Tesis Sekolah Pascasarjana, Institut Pertanian Bogor.

Chambers, Robert. (2013). Rural Development: Putting The Last First. Title, USA, New York.

Kusnadi ,dkk. 20009. 6 Tahun Program PEMP: Sebuah Refleksi. Jakarta: Direktorat Pemberdayaan Masyarakat Pesisir, Ditjen Kelautan, Pesisir, dan Pulau-Pulau 
Kecil, Departemen Kelautan dan Per-ikanan.

Sumodiningrat, Gunawan. (2009). Pembangunan Ekonomi Melalui Pembangunan Pertanian, PT Bina Rena Pariwara, Jakarta.

(2009). Pembaharuan Sosial Desa sebagai Syarat Kemajuan Desa: Kecamatan sebagai Pusat Pertumbuhan Ekonomi Daerah, dalam Julianta, Dadang. Arus Bawah Demokrasi, Otonomi, dan Pemberdayaan Desa. Yayasan LAPERA Indonesia, Yokyakarta.

Suyanto, Bagong. (2016). Perangkap Kemiskinan: Problem dan Strategi Pengentasannya dalam Pembangunan Desa. ADITYA Media, Yokyakarta. 